\title{
Personality Development in English Medium and Odia Medium School Children
}

\author{
Manaswini Dash ${ }^{1}$, Avipsa Senapati ${ }^{2}$ \\ 1 (Utkal University, Bhubaneswar, Odisha, India \\ 2 (Utkal University, Bhubaneswar, Odisha, India)
}

\begin{abstract}
The present study was designed to examine the differences between the children taught in English medium \& those taught in Odia medium schools along the various personality dimensions. For this purpose, a sample of 40 children studying in English medium and 40 Odia medium school children, 20 each from grade IV (aged 8-9 years) and grade VI (aged 10-11 years) were administered the Children's Personality Questionnaire (Porter \&Cattell, 1972). The data were statistically analyzed with the help of 2 (Medium of Instruction) X 2 (Grade) Analyses of Variance. The result revealed significant differences in some of the personality factors suggesting that the English medium school children are more intelligent, impatient, dependent, guarded, tenderminded, forthright, and careless of social rules than their Odia medium counterparts. They tend to show off a lot to get important positions and prefer to act individualistically. Grade VI children were found to be more intelligent, assertive and patient than the grade IV children. So far as intelligence is concerned with increased years of exposure to English medium schooling the gap between the two groups widen. The results were interpreted in terms of the differential curriculum and the teaching-learning environments of both types of schools.
\end{abstract}

Key words: Bilingualism, Bilingual education, Medium of Instruction, Mother tongue, Personality differences

\section{Introduction}

Language is the very essence of human life. India being a multilingual country, it has been a major topic of concern among the academicians, psychologists and politicians as well, since India's independence. There are 1576 languages used as mother tongues (according to 1991 census), twenty-two official languages (according to the eighth schedule of the Constitution of India) in this country whereas the administration of the country is run on thirteen different languages. Hence, multilingualism is inherent in Indian cultural diversity. Taking India's diverse multilingual culture into consideration, the National Curriculum Framework (NCF)-2005 strongly advocates multilingualism in school education and prescribed the mother tongue of children to be the medium of instruction. The suggestions of the NCF-2005are backed by a number of researchers who, on sound pedagogical grounds, argue that the mother tongue is the most suitable as the medium of instruction. To them, originality in thought and expression can most effectively be achieved in the language with which one lives and grows (Mohanty, 1989; Pattanaik, 1991).

It should be kept in mind that the NCF-2005, in addition to education through mother tongue, also advocates for multilingual education as English learning cannot be spared in this country from practical point of view. In fact, it has been strongly argued for the implementation ofthe three language formula in its true spirit, for promoting multilingual communicative abilities in a multilingual country (NCF-2005).

According to Cummins (1979), instruction in $\mathrm{L}_{1}$ (first language) and consequent proficiency in $\mathrm{L}_{1}$ provides a sound base for the development of proficiency in $\mathrm{L}_{2}$ (English). Cummins (1982) maintains that cognitive skills and conceptual knowledge can be transferred from the native language to English. In this context, he talks of cognitive academic language proficiency (CALP) that is crucial in achieving academic success. Since language development and cognitive development go hand in hand (Pattanayak, 1991), the child must concentrate on the development of language skills in $\mathrm{L}_{1}$ so that he achieves the CALP required for learning a second language in school. CALP provides a "preexisting knowledge base for making inferences and predictions" in the $\mathrm{L}_{2}$ (Saville-Troke, 1988). Thus, a child who has learned a concept in mother tongue or $\mathrm{L}_{1}$ should be able to transfer this knowledge to English or $\mathrm{L}_{2}$ without having to relearn the concepts as long as the relevant vocabulary in $\mathrm{L}_{2}$ (English) is available (Hakuta, 1990).

The above mentioned views can prompt one to believe that mother tongue or the regional language is the most suitable medium of instruction for children in India. But, contradictions to this belief are also there. There are some academicians as well as researchers who point out that where English is taught only as a language, or as a subject, students fail to acquire adequate linguistic and cognitive competence. Hence they argue for English as the medium of instruction right from pre-primary and primary level. And this latter view is perhaps one of the major factors responsible for the increase in the preference among the parents for English 
medium schooling of their children. This preference can be easily understood from the present social scenario of mushrooming of English Medium Schools throughout the country.

So far as the effects of bilingual education, that is, using a language other than one's own mother tongue as the medium of instruction on psychological, cognitive, linguistic constructs as well as academic achievement are concerned, literature provides mixed findings.

A number of studies (Brigham,1923; Carrow,1957; Darcy,1946; Goodenough,1926; Grosjean,1982; Saer,1923;Tireman,1955) have found bilingual education to be an obstacle to both cognitive and linguistic development. These findings have been explained in physiological terms like human beings' limited neural capacity for language learning (Macnamara, 1966) as well as in emotional terminology like fear of losing one's own linguistic identity (Ramaswamy, 2001).

On the other hand, contradictory findings are also available which suggest that bilingual education in general and bilingual education in particular, is a great asset to the child. It has been noted that the bilingual child is better equipped with the ability to appreciate differences among various languages and hence, is better at learning new language (Edwards, 1995;Gonazales\&Yawkey, 1994; Hawson, 1997, Kirikici, 2004; Patra \& Babu, 1999, Roseberry- M'ckibbinn\& Brice, 2000;Srivastava \&Khatoon, 1980; Varkuti, 2009). Peal and Lambert (1962), claimed that the bilingual children have mental flexibility, a superiority in concept formation and a more diversified set of mental abilities which facilitates their intellectual and cognitive growth. Since they have already developed a syntactic orientation to language, they are more aware of the dichotomy between the structure and meaning in language. They are better able to dissociate concepts from the words with which they are verbalized.

Recent studies (Bialystok, 2007; Feng, Bialystok,\& Diamond, 2009)showing cognitive advantages in bilingual children suggest that bilingualism's demand on executive functions for constantly switch languages and exerting inhibitory control to suppress the mother tongue in class-room context contribute to the attainment of cognitive flexibilities. However, such linguistic and cognitive flexibilities achieved through instructions in a language other than the mother tongue have catalytic effect on cognitive growth (Senapati, Patnaik, \& Dash, 2012a).

While there is no consensus regarding the role of bilingual education on cognitive development, Studies by Nadamba (2008) and Sinha (2005) have documented a preference among the students as well as their parents for education through English rather than mother tongue. Throughout the world, in non-English speaking countries a change in attitude among the younger generation as well as their parents towards English medium schooling can be witnessed in recent days. This is reflected in the mushrooming of English medium schools, even in rural areas. It is believed that English language offers greater mobility and self-confidence, enhancing self-esteem. People taught in English medium schools are smarter and more competent. However, research supporting such type of belief are not plentily available, though very few studies (Senapati, Patnaik, \& Dash, 2012b) have documented some differences in personality characteristics of English and Odia medium school children.

In the context of present social scenario of parents in Odisha being strongly aversive of getting their children educated in Odia medium schools and preferring English medium schools with the resultant mushroom growth of the latter, it is necessary to examine the actual changes brought about by English medium schooling/bilingual schooling in different dimensions of personality. The present study attempts to ascertain the effects of mother tongue vis-à-vis other tongue as the medium of instruction on various personality dimensions from a developmental perspective.

\subsection{Design of the Study}

\section{Method}

The present study employed a 2 (Medium of Instruction) X 2 (Grade) factorial design.

\subsection{Sample}

The sample consisted of eighty children from which forty children were studying in grade IV and forty children in grade VI. In each class twenty children were taken from an English medium school and twenty were studying in Odia medium. The English medium children were selected from KendriyaVidyalaya, Cuttack which is an English medium school and the children studying in Odia medium were selected from Saraswati Sishu Mandir, Cuttack. Both the schools were comparable in terms of infrastructural facilities. The children studying in class-IV were from the age group of ( 8-9 years) and those studying in class-VI, were from (11-12years). The sample included both male and female school children. All the children were from middle socio economic background. The mother tongue of all the children was Odia. Consent of the participants was taken before the administration of the test. 


\subsection{Instrument}

Children's Personality Questionnaire (CPQ). This is a standardized test of personality developed by Porter \& Cattle (1972) which intended for an age range of 8-12 years. The test has two parts, each consisting of 70 items and thus the total 140 items measure fourteen personality traits (namely, A, B, C, D, E, F, G, H, I, J, N, $\mathrm{O}, \mathrm{Q} 3$ \& Q4). Each item offers two statements requiring the child to indicate the one which better fits him. However, some of the questions have three options. The options are either scored one or zero. Some of the items in the original test were modified by Patnaik, Dash, \& Senapati (2012) in order to make it suitable for use in Indian culture. Moreover the test was translated into Odia by Patnaik, Dash, and Senapati (2012) for using it with children studying in Odia medium schools. The correlation between the English and Odia version of the test for all the fourteen factors were found to be highly significant (Pearson's $r$ ranging from .81 to .98).

\subsection{Procedure}

Prior to collection of the data, permission was obtained from the Principal/Head master of the respective schools. Test administration was carried on after establishing rapport with the children. The children were administered the CPQ in group by the investigator in a separate room provided by the respective school authorities. The English medium children were administered the English version of the test while the Odia medium children, the Odia version of the test. The responses of the different groups of children were scored according to the manual. The data were analyzed statistically.

\section{Results and Discussion}

In order to examine the differences in the development of various personality traits as a function of medium of instruction, the scores 40 English medium and 40 Odia medium school children, 20 each from grade IV and grade VI on fourteen different dimensions of the Children's Personality Questionnaire were subjected to 2X2 Analyses of Variance. The group means and Standard Deviations of the grade IV and grade VI Odia and English medium school children are presented in Table 1.

Table 1. Mean and Standard Deviation of Grade-IV and Grade-VI Odia and English Medium School Children( $\mathrm{N}=20$ in each group)

\begin{tabular}{|c|c|c|c|c|c|}
\hline \multirow{2}{*}{\multicolumn{2}{|c|}{ Personality Factors }} & \multirow{2}{*}{\multicolumn{2}{|c|}{ Odia Medium }} & \multirow{2}{*}{\multicolumn{2}{|c|}{ English Medium }} \\
\hline & & & & & \\
\hline Factor A & $\begin{array}{l}\text { Mean } \\
\text { SD }\end{array}$ & $\begin{array}{l}7.45 \\
1.46\end{array}$ & $\begin{array}{l}7.05 \\
1.70\end{array}$ & $\begin{array}{l}7.60 \\
1.60\end{array}$ & $\begin{array}{l}7.00 \\
1.45\end{array}$ \\
\hline Factor B & $\begin{array}{l}\text { Mean } \\
\text { SD }\end{array}$ & $\begin{array}{l}5.45 \\
1.46\end{array}$ & $\begin{array}{l}6.50 \\
1.19 \\
\end{array}$ & $\begin{array}{l}5.85 \\
1.53 \\
\end{array}$ & $\begin{array}{l}8.20 \\
1.98 \\
\end{array}$ \\
\hline Factor $\mathrm{C}$ & $\begin{array}{l}\text { Mean } \\
\text { SD }\end{array}$ & $\begin{array}{l}6.90 \\
1.44\end{array}$ & $\begin{array}{l}7.00 \\
1.33\end{array}$ & $\begin{array}{l}7.35 \\
.93\end{array}$ & $\begin{array}{l}6.90 \\
1.74\end{array}$ \\
\hline Factor D & $\begin{array}{l}\text { Mean } \\
\text { SD }\end{array}$ & $\begin{array}{l}2.45 \\
1.35\end{array}$ & $\begin{array}{l}2.05 \\
1.19\end{array}$ & $\begin{array}{l}3.65 \\
1.66\end{array}$ & $\begin{array}{l}2.60 \\
1.23\end{array}$ \\
\hline Factor $\mathrm{E}$ & $\begin{array}{l}\text { Mean } \\
\text { SD }\end{array}$ & $\begin{array}{l}3.25 \\
1.20\end{array}$ & $\begin{array}{l}2.05 \\
1.23\end{array}$ & $\begin{array}{l}2.55 \\
1.50\end{array}$ & $\begin{array}{l}2.25 \\
1.37\end{array}$ \\
\hline Factor $\mathrm{F}$ & $\begin{array}{l}\text { Mean } \\
\text { SD }\end{array}$ & $\begin{array}{l}3.50 \\
1.39\end{array}$ & $\begin{array}{l}3.80 \\
1.15\end{array}$ & $\begin{array}{l}4.00 \\
1.91\end{array}$ & $\begin{array}{l}3.45 \\
2.01\end{array}$ \\
\hline Factor $\mathrm{G}$ & $\begin{array}{l}\text { Mean } \\
\text { SD }\end{array}$ & $\begin{array}{l}7.40 \\
1.39\end{array}$ & $\begin{array}{l}7.40 \\
1.04\end{array}$ & $\begin{array}{l}7.65 \\
1.26\end{array}$ & $\begin{array}{l}7.70 \\
1.59\end{array}$ \\
\hline Factor $\mathrm{H}$ & $\begin{array}{l}\text { Mean } \\
\text { SD }\end{array}$ & $\begin{array}{l}5.85 \\
1.34\end{array}$ & $\begin{array}{l}6.25 \\
1.25\end{array}$ & $\begin{array}{l}6.35 \\
1.34\end{array}$ & $\begin{array}{l}6.30 \\
1.45\end{array}$ \\
\hline Factor I & $\begin{array}{l}\text { Mean } \\
\text { SD }\end{array}$ & $\begin{array}{l}5.85 \\
1.49\end{array}$ & $\begin{array}{l}5.90 \\
1.48\end{array}$ & $\begin{array}{l}6.75 \\
1.37\end{array}$ & $\begin{array}{l}7.00 \\
1.65\end{array}$ \\
\hline Factor J & $\begin{array}{l}\text { Mean } \\
\text { SD }\end{array}$ & $\begin{array}{l}3.25 \\
1.83\end{array}$ & $\begin{array}{l}3.40 \\
.99\end{array}$ & $\begin{array}{l}3.85 \\
1.92\end{array}$ & $\begin{array}{l}4.80 \\
1.19\end{array}$ \\
\hline Factor $\mathrm{N}$ & $\begin{array}{l}\text { Mean } \\
\text { SD }\end{array}$ & $\begin{array}{l}3.25 \\
1.71\end{array}$ & $\begin{array}{l}2.65 \\
1.30\end{array}$ & $\begin{array}{l}2.50 \\
1.31\end{array}$ & $\begin{array}{l}2.15 \\
1.34\end{array}$ \\
\hline Factor $\mathrm{O}$ & $\begin{array}{l}\text { Mean } \\
\text { SD }\end{array}$ & $\begin{array}{l}2.70 \\
1.41\end{array}$ & $\begin{array}{l}3.55 \\
1.95 \\
\end{array}$ & $\begin{array}{l}3.35 \\
1.89\end{array}$ & $\begin{array}{l}3.80 \\
1.98\end{array}$ \\
\hline Factor Q3 & $\begin{array}{l}\text { Mean } \\
\text { SD }\end{array}$ & $\begin{array}{l}8.25 \\
2.07\end{array}$ & $\begin{array}{l}8.65 \\
1.38\end{array}$ & $\begin{array}{l}6.75 \\
2.59\end{array}$ & $\begin{array}{l}7.65 \\
1.84\end{array}$ \\
\hline Factor Q4 & $\begin{array}{l}\text { Mean } \\
\text { SD }\end{array}$ & $\begin{array}{l}3.00 \\
1.83\end{array}$ & $\begin{array}{l}1.75 \\
1.33\end{array}$ & $\begin{array}{l}2.45 \\
1.90\end{array}$ & $\begin{array}{l}2.35 \\
1.72\end{array}$ \\
\hline
\end{tabular}

The results of 2X2 ANOVA for the personality factors are presented in Table 2. 
Personality Development in English Medium and Odia Medium School Children

Table 2. F values Showing the Main and Interaction Effects of Medium of Instruction, Grade on the Personality Dimensions

\begin{tabular}{|c|c|c|c|c|c|c|c|c|c|c|c|c|c|c|}
\hline \multirow{2}{*}{$\begin{array}{l}\text { Sources of } \\
\text { Variance }\end{array}$} & \multicolumn{14}{|c|}{ Personality Factors } \\
\hline & A & B & $\mathrm{C}$ & $\mathrm{D}$ & $\mathrm{E}$ & $\mathrm{F}$ & $\mathrm{G}$ & $\mathrm{H}$ & I & $\mathrm{J}$ & $\mathrm{N}$ & $\mathrm{O}$ & Q3 & Q4 \\
\hline Medium & .021 & $8.93^{\text {** }}$ & .314 & $8.12^{* * *}$ & .702 & .041 & .843 & .827 & $8.83^{* *}$ & $8.43^{\text {** }}$ & 3.81 & 1.21 & $7.65^{* *}$ & .004 \\
\hline Grade & 2.06 & $23.4^{* *}$ & .314 & $5.58^{*}$ & $6.32^{*}$ & .114 & .007 & .335 & .199 & 2.55 & 2.20 & 2.52 & 2.07 & 3.10 \\
\hline $\begin{array}{l}\text { Medium X } \\
\text { Grade }\end{array}$ & .082 & $3.42^{@}$ & .776 & 1.12 & 2.27 & 1.31 & .007 & .553 & .088 & 1.35 & .152 & .239 & .306 & 2.25 \\
\hline
\end{tabular}

$* * * \mathrm{p}<.001, * * \mathrm{p}<.01, * \mathrm{p}<.05, @ \mathrm{p}<.1$

From table 2, it can be noticed that the effect of medium of instruction is significant for factor B, D, I, $\mathrm{J}$, and Q3; and marginally significant for factor $\mathrm{N}$. The main effect of grade is significant for factor $\mathrm{B}, \mathrm{D}$, and $\mathrm{E}$, while for Q4, it is marginally significant. For none of the factors a significant interaction effect was obtained, except for factor $\mathrm{B}$, for which it is marginally significant.

So far as factor $\mathrm{A}$ is concerned, neither the main effects of medium of instruction and grade nor the medium $\mathrm{X}$ grade interaction is significant. This implies that the English medium and Odia medium students are comparable in terms of factor A of the CPQ. Factor A provides a measure of the extent to which the child is expressive. Those persons who score low on this scale tend to be reserved, cool, aloof, rigid, critical, and prone to sulk. On the other hand persons who fall at the higher end of this scale are usually warm hearted, outgoing, easygoing, participative, adaptable and active. The result of the present study thus contradicts the popular belief that children studying in English medium schools are smarter than Odia medium school children.

It can be noticed that the effects of the medium of instruction and grade are significant for personality factor B which provides a measure of general mental ability. Those person who score low on this scale tend to be low in intelligence, and are unable to handle abstract problems. On the other hand persons who fall at the higher end of this scale are usually intelligent, bright, insightful and fast-learning. It is quite natural to get significantly higher scores in grade VI children than their grade IV counterparts in both the types of schools as this dimension of the test is developmentally sensitive. The English medium school children were found to outperform their Odia medium counterparts. Moreover a marginally significant medium X grade interaction effect was also obtained suggesting that the difference between the English and Odia medium children becomes wider with increasing numbers of schooling. Earlier studies have also shown cognitive advantages in bilingual children, in general (Bialystok, 2007; Feng, Bialystok, \& Diamond, 2009) and Odia children getting their education through English, in particular (Senapati, Patnaik, \& Dash, 2012a). This has been explained in terms of cognitive flexibilities achieved through bilingualism's demand on executive functions for constantly switching between languages and exerting inhibitory control to suppress the mother tongue in class-room context. Such linguistic and cognitive flexibilities contribute to cognitive growth.

Factor D provides a measure of the extent of distractibility, over activity. Persons with high factor D score tend to be of showing-off type. Considering the significant main effects of medium of instruction as well as grade from Table 2 and group means from Table 1 together, it can be said that with increasing age children become more and more patient. Children studying in English medium schools are found to be more distractible and impulsive than their Odia medium counterparts. The former group of subjects tend to show off more than the latter group of children. However, this quality gradually decreases with age. The findings are in conformity with Senapati, Patnaik and Dash (2012b).

English medium school children are significantly higher than their Odia medium counterparts in factor I which measures harria vs. premsia dimension of personality. Persons scoring high on this scale are usually tender-minded, sensitive, dependent and overprotected, neat but not organized. On the other hand, low scoring individuals tend to be tough-minded, self-reliant, hard, and practical and realistic rejecting illusion. Research has shown that high I is associated with indulgent, over-protected and more fastidiously cultured homes (Cattell. 1957). This is quite expected as it is a common observation in Odisha that children studying in English medium schools mostly come from upper class and upper-middle class families in which parents are usually overcautious for their children's development as well as achievements. Their over-cautious nature together with their well-to-do financial condition make them over-protective parents, as a result of which their children develop a sensitive and dependent type of personality.

English medium school children are also found to be significantly higher on factor J. The persons obtaining high scores on this scale are usually reflective, wrapped up in self, individualistic, guarded and internally restrained. On the other hand persons falling at the lower end tend to like group action. The results of the present study suggests that the English medium school children seem to act individualistically. They tend to be internally more restrained and guarded in comparison to their Odia medium counterparts. Probably, the curriculum as well as the teaching-learning atmosphere in English medium schools promote individual activity and competitive spirit. 
A significant difference between the English and Odia medium school children in factor Q3 dimension of their personality favouring the latter has been found. Those person who score low on this scale tend to be uncontrolled, lax and careless of social rules. On the other hand, persons who fall at the higher end of this scale are usually controlled, compulsive, socially precise and follow self-image. It is also evident from Table 1 that the mean scores of both the groups which is based on sten scores are above average( sten scores of five and six are considered as average). Therefore, one can say that English medium school children are concerned with their self-image, though comparatively less than their Odia medium counterparts.

A marginally significant main effect of medium of instruction on factor $\mathrm{N}$ suggests that the English medium school children are slightly more genuine in their expressiveness of emotions and natural warmth than the students studying in Odia medium schools.

\section{Conclusion}

English is a language which is spoken worldwide. That is why it is a highly esteemed language. In India, there is a belief that people taught in English medium schools are more competent and successful in their academic as well as occupational life. However, while research documenting advantage of English medium schooling over education through mother tongue in terms of cognitive development (Senapati, Patnaik, \& Dash, 2012a; Varkuti, 2009) are plentily available, very few studies (Senapati, Patnaik, Dash, 2012b) have reported the effect of medium of schooling on personality development. The results of the present study revealed that the children getting their education through English which is not their mother tongue are significantly more intelligent, impatient, dependent, guarded, tender-minded, genuine and forthright, and careless of social rules than their Odia medium counterparts. They tend to show off and prefer to act individualistically. Grade VI children were found to be more intelligent and patient. With increased years of schooling in English medium schools the gap between the two groups widen.

Personality traits are largely learned, though the impact of heredity cannot be denied. The differences between the English and Odia medium school children in the above mentioned traits suggests that the teachinglearning environment in English medium schools as well as the school curriculum might be fostering the development of these personality traits.

\section{References}

[1]. NCERT, (2005).National Curriculum Framework- 2005 New Delhi, India.

[2]. Mohanty, A. K (1989). "Psychological consequences of mother tongue maintenance and thelanguage of literacy for the linguistic minorities in India",Psychology and Developing Societies, 2(1), 31-51.

[3]. Pattanayak, D. P. (1991).Language, education and culture.Mysore : CentralInstitute of Indian Languages.

[4]. Cummins, J. (1979), "Linguistic interdependence and educational development of bilingual children",Review of Educational Research, 49, 222-25.

[5]. Saville-Troike, M. (1988).“Teaching and testing for academic achievement; perspectiueson an all- structured domain”.Unpublished manuscript.

[6]. Hakuta, K. (1990). "Bilingualism and bilingual education: A research perspective, focus no. I", Washington, DC: National Clearinghouse for Bilingual Education.

[7]. Brigham, C.C. (1923). A study of American Intelligence. Princeton, NJ: Princeton University Press.

[8]. Carrow, S. (1957).Linguistic functioning of bilingual \& monolingual children.Journal of speech \& hearing disorders, 22,371-380.

[9]. Darcy, N. (1946). The effect of bilingualism upon the measurement of the intelligence of children of preschool age. Journal of Educational Psychology, 37, 31 - 44.

[10]. Goodenaugh, F. (1926). Racial differences in the intelligence of school children. Journal of Experimental psychology, 9,388-397.

[11]. Grosjean, F. (1982).Life with two languages: An introduction to bilingualism. Massachusetts: Harvard University Press.

[12]. Saer, O. J. (1923). The effects of bilingualism on intelligence. British Journal of Psychology, 14, 25-28.

[13]. Tireman, L. (1955). Bilingual child and his reading vocabulary. Elementary English, 32, 33-35.

[14]. Macnamara, J. (1966). Bilingualism and primary education. Edinburgh: Edinburgh University Press.

[15]. Ramaswamy, K. (2001). Mother tongue and medium of instruction- A continuing battle in India. Language in India, 1:6.

[16]. Edwards, J.C. (1995). Multiiingualism, London: Penguin Books.

[17]. Gonzales, V. \&Yawkey, T. D. (1994). Influence of cognitive, linguistic and socio cultural factors on literacy \&biliteracy in young bilingual children. Education, 115,230 -239.

[18]. Hawson, A. (1997). Paying attention to attention allocation in second-language learning; Some insights into the nature of linguistic thresholds. Bilingual Review, 22,31-48.

[19]. Kirkici, B. (2004). Foreign language medium instruction and bilingualism: The analysis of myth. SosyalBilmlerDergise, $2,109-121$.

[20]. Patra, S. \&Babu.N. (1999).Role of second language as the medium of instruction.In U.N. Dash \& U. Jain (eds.), Perspectives on psychology and social devolvement.New Delhi: Concept Publishing Company.

[21]. Roseberry- Mckibbin, C. \& Brice, A. (2000).Acquiring English as a second Language, ASHA Leader, 5, 4 - 6.

[22]. Srivasta, A.K. \&Khatoon, R. (1980).Effect of difference between mother tongue and other tongue as medium of instruction on achievement, mental ability, and creativity of VIII standard children.In E. Annamalai (ed.) Bilingualism and Achievement in school.Mysore:Central Institution of Indian languages.

[23]. Varkuti, A. (2009). Biology-based analogous reasoning in the target language in Hungarian - English high Schools. A biologia taniiasa, XVIII,3-14. http://www.devcogneuro.com/ Publications / Fen_Bialystok_Diamond.

[24]. Peal, E. \& Lambert, W. E. (1962). Relation of biligualism to intelligence. Psychological Monographs, 76,1-:23.

[25]. Bialystok, E. (2007). Cognitive effects of bilingualism: How linguistic experience leads to cognitive change. The International Journal of Bilingual Education and Bilingualism, 10,210-223.

[26]. Feng,X., Bialystok,E., Diamond,A., (2009), "Do Bilingual Children show an Advantage In Working Memory?", 1- 
41.http://www.devcogneuro.com/Publications/Feng_Bialystok_Diamond.

[27]. Senapati, P., Patnaik, N., \& Dash, M., (2012a). Role of medium of instruction on the development of cognitive processes.Journal of Education and Practice, 3 (2), 58-66.

[28]. Senapati, P., Patnaik, N., \& Dash, M., (2012b).Personality differences among english medium and odia medium school children. Social Science International, 28 (1), 177-185.

[29]. Ndamba, G. T. (2008). Mother tongue usage in learning: An examination of language preferences in Zimbabwe. The Journal of Pan African studies, 2, 171-189.

[30]. Sinha, S. (2005). Oriya Language - process of decay? A socio-linguistic study. Language in India, 5.

[31]. Porter, R. B. \&Cattell, R. B.(1972).The Children's Personality Questionnaire.Illinois: Institute for Personality and Ability Testing.

[32]. Cattell, R. B. A universal index for psychological factors. Psychologia, 1957, 1, 74-85 (a). 